\title{
Factors Associated with Obesity among School Going Girls of Kumaun Region of Uttarakhand, India
}

\author{
Janki Joshi* and Ekroop Kaur \\ Department of Home Science, Surajmal Agarwal Private Kanya Mahavidyalaya, \\ Kichha -263148, Uttarakhand, India \\ *Corresponding author
}

\section{A B S T R A C T}

\section{Keywords \\ Obesity, \\ Overweight, \\ Underweight and \\ Adolescent}

Article Info

Accepted:

10 September 2019

Available Online:

10 October 2019
Present research aimed to study the factors associated with obesity among school going girls of Kumaun region of Uttarakhand. The multi-stage, purposive cum random sampling techniques was used to select the study area i.e. state, district, block, villages, school and school going girls from selected school. The Uttarakhand state's Kumaun region was selected purposively. Haldwani and Bajpur block from district Nainital and Udham Singh Nagar respectively were selected purposively. Total sample sizes comprised of 100 school going girls were selected randomly from the two schools namely Government Girls Inter College and Adarsh Kanya Inter College which were selected purposively from the above blocks. Total 15 per cent school going girls were found to be overweight followed by nine percent obese whereas 20 per cent were underweight. Chi-square tests were found to be significant at 5\% level for low level of parent education, taking non vegetarian diet and eating outside food, having more than three meals per day, eating sweet and fried food, eating ice cream, chocolate and bakery product more frequently, less participation in outdoor games, and as compared to indoor games, sitting and watching TV for long hours in free time. All these factors showed a strong association with a higher BMI lead to overweight and obesity in school going girls.

\section{Introduction}

Childhood and adolescent i.e. age 10-18 years is the vital stage of growth and development of child. It is a critical period as growth spurt occurs during this phase of life it become more crucial in terms of nutrition. Obesity also adversely affects the hormonal development of the adolescent girls. Now a day's obesity and overweight are serious health issues among school going children. As obesity, leads to many long-term physiological and psychological health risks. Earlier it was considered as a problem of western countries and people from higher economic backgrounds, but now the scenario is changing. The prevalence is increasing day by day in adolescents everywhere. Rates of obesity among adolescents in India have increased at a dramatic rate along with the 
prevalence of weight-related diseases. Because the obese female adolescent faces medical, psychological, and reproductive health challenges, early intervention is imperative in preventing short-term and longterm morbidity. According to a report from urban South India, 21.4 per cent of boys and 18.5 per cent of girls aged 13-18 years were overweight or obese. The prevalence of obesity among School children in India has been reported between 5.74 per cent and 8.82 per cent Alok et al., (2012). The proportion of adolescents who are overweight or obese is rapidly increasing worldwide. Adolescence is a vulnerable period for the development of obesity and also appears to be a critical period for establishing risk factors for some chronic diseases in adulthood Campbell et al., (2007).

School age is associated with changes in eating and activity behaviors in girls. Less reliance on parental provision and choice of food, coupled with a decrease in participation in physical activity and sport, can create an energy imbalance, predisposing to weight gain. Physiological alterations to body composition, reduction in insulin sensitivity, and psychological adjustments may further amplify the risk of becoming overweight and maintaining an unhealthy level of body fat into childbearing years. Beside these the causes of obesity are complex and include genetic, biological, behavioral and cultural factors. Obesity occurs when a person eats more calories than the body burns.

Obesity in childhood and adolescence can be related to poor eating habits, overeating or binging. Foods regularly like fast foods, baked goods and vending machine snacks increases weight. The major ill effect of fast food consumption is obesity. Thus, the present study was conducted to study the factors associated with obesity among school going girls.

\section{Materials and Methods}

In present study descriptive cum action research design was chosen. Interview schedule was used for data collection. For the present study, Uttarakhand state, Kumaun region was selected purposively as the investigator belonged to it. Districts Nainital and Udham Singh Nagar were selected purposively from the state as these were near to the place of residence of the investigator, Haldwani and Bajpur block from district Nainital and Udham Singh Nagar respectively were selected purposively. Total two schools, one from each block were selected purposively as location of these villages were within the reach of investigator. For selection of sample, simple random sampling technique was used. Total 100 school going girls were selected using simple random sampling technique; 50 from each school were selected randomly from the list of all girls of each school.

\section{Measurement of weight}

One suitable weight balance (Virgo mechanical personal scale) was used. This scale was standardized daily by using standard five $\mathrm{kg}$ weight. Students were weighed while wearing school uniform, stand erect, without the shoes and see in front with both the hands placed on thigh. The weight was recorded to the nearest accuracy of $0.5 \mathrm{~kg}$.

\section{Measurement of height}

Height of the subjects was measured by using non-stretchable fiber glass measuring tape. The subjects were allowed to stand straight on a flat floor against the wall without footwear. They were made to stand such that their head, back, shoulder, buttocks and heels touched the wall and their head was positioned erect. A horizontal scale was gently placed over the head of the subjects without pressing and a 
mark was made on the wall. The distance between the position of head and toe was measured using the non-stretchable fiber glass measuring tape and the height was recorded for all subjects to the nearest accuracy of 0.1 $\mathrm{cm}$.

\section{Calculation of body mass index}

Using standard procedures, anthropometric measurements of height and weight were recorded and the corresponding Body Mass Index was calculated for the entire respondent. The Body Mass Index (BMI) was calculated using the following formula.

Body Mass Index = weight $/$ height $^{2}$

The selected school going girls were grouped based on the WHO, 2007 BMI (z Scores) as given in Table 1.

\section{Statistical analysis}

For hypothesis testing chi-square and student t-test were applied. Significance level was accepted at $\mathrm{p} \leq 0.05$.

\section{Results and Discussion}

Distribution of the school going girls according to their age groups

According to their age respondents were categorized in three different groups that are 10-12 years, 13-15 years and 16-18 years. Some analysis of the study was done on the basis of age group. It was found that 62 per cent respondents falls under age group of 1618 years and 33 per cent respondents fall under age group of 13-16 years while only five per cent respondents fall under the age group of 10-12 years.

Total mean age of the respondents was $15.79 \pm 1.50$ years.

Age wise prevalence of overweight/obesity among school going girls

It was observed that under age group of 10-12 years 60 per cent respondents were normal whereas only 20 per cent respondent were under weight and overweight. It was found that none of the respondents in this age group was obese. Under the age group of 13-15 years 15.15 per cent school going girls were obese followed by 9.09 per cent were overweight and 69.69 per cent were normal but 6.06 per cent were under weight. Under the age group of $16-18$ years 6.45 per cent school going girls were obese followed by 17.74 per cent were overweight and 48.38 per cent were found to be normal whereas only 27.41 per cent were under weight (Table 2).

\section{Factors associated with obesity}

\section{Parent's education}

It was found that there was significant association between obesity and parent's education (Table 3). Similar findings were seen in the study done by Bharati et al., (2008) wherein the risk of overweight/obesity was significantly higher in children whose father and/or mother had education $>6$ th standard.

Table.1 Classification of Body Mass Index Status

\begin{tabular}{|l|l|}
\hline Z-scores (BMI in $\mathbf{~ k g} / \mathbf{m} 2)$ & Body Mass Index Status \\
\hline <-2 SD & Under weight \\
\hline -2 SD - 2 SD & Normal \\
\hline 2 SD - 3SD & Obese \\
\hline >3 SD & Obesity \\
\hline
\end{tabular}


Table.2 Age wise prevalence of overweight/obesity among school going girls $(n=100)$

\begin{tabular}{|c|c|c|c|c|}
\hline \multirow{2}{*}{ BMI Category } & \multicolumn{2}{|c|}{ Age wise distribution of the school going girls } & \multirow{2}{*}{$\mathbf{N = 1 0 0 ( \% )}$} \\
\cline { 2 - 4 } & $10-12$ years & $13-15$ years & $16-18$ years & \\
\hline Underweight & $1(20)$ & $2(6.06)$ & $17(27.41)$ & 20 \\
\hline Normal & $3(60)$ & $23(69.69)$ & $30(48.38)$ & 56 \\
\hline Overweight & $1(20)$ & $3(9.09)$ & $11(17.74)$ & 15 \\
\hline Obese & $0(0)$ & $5(15.15)$ & $4(6.45)$ & 9 \\
\hline
\end{tabular}

Table.3 Chi-square for prevalence of obesity and parent's education

\begin{tabular}{|c|c|c|c|c|c|}
\hline \multirow[t]{2}{*}{ Level of education } & \multicolumn{4}{|c|}{ BMI category } & \multirow[t]{2}{*}{$P$ value } \\
\hline & Underweight & Normal & Overweight & Obese & \\
\hline \multicolumn{5}{|l|}{ Mother's education } & \multirow{6}{*}{$0.00416^{*}$} \\
\hline Illiterate & 2 & 11 & 9 & 2 & \\
\hline Primary & 8 & 19 & 0 & 5 & \\
\hline High School & 3 & 15 & 1 & 2 & \\
\hline Intermediate & 7 & 9 & 3 & 0 & \\
\hline Graduate & 0 & 2 & 2 & 0 & \\
\hline \multicolumn{6}{|l|}{ Father's education } \\
\hline Illiterate & 1 & 8 & 2 & 3 & \multirow{6}{*}{$0.000127054 * *$} \\
\hline Primary & 5 & 16 & 2 & 2 & \\
\hline High School & 3 & 8 & 2 & 2 & \\
\hline Intermediate & 4 & 16 & 5 & 1 & \\
\hline Graduate & 3 & 8 & 2 & 1 & \\
\hline Above graduate & 4 & 0 & 2 & 0 & \\
\hline
\end{tabular}

Table.4 Chi-square for prevalence of obesity and food habit of school going girls

\begin{tabular}{|c|c|c|c|c|c|}
\hline \multirow[t]{2}{*}{ Characteristics } & \multicolumn{4}{|c|}{ BMI category } & \multirow[t]{2}{*}{$P$ value } \\
\hline & Underweight & Normal & Overweight & Obese & \\
\hline \multicolumn{6}{|l|}{ Dietary habits } \\
\hline Vegetarian & 15 & 41 & 3 & 0 & \multirow[t]{2}{*}{$2.06 \mathrm{E}-06^{* *}$} \\
\hline Non vegetarian & 5 & 15 & 12 & 9 & \\
\hline \multicolumn{6}{|l|}{ Food preference } \\
\hline Homemade & 15 & 47 & 6 & 0 & \multirow[t]{2}{*}{$6.64014 \mathrm{E}-07$} \\
\hline Outside & 5 & 9 & 9 & 9 & \\
\hline \multicolumn{6}{|l|}{ Type of food liked } \\
\hline Sour food & 0 & 2 & 0 & 0 & \multirow[t]{4}{*}{$0.000229 * *$} \\
\hline Spicy food & 16 & 30 & 1 & 0 & \\
\hline Fried food & 1 & 14 & 9 & 6 & \\
\hline Sweet food & 3 & 10 & 5 & 3 & \\
\hline \multicolumn{6}{|c|}{ No of meal per day } \\
\hline Two meal & 0 & 0 & 0 & 2 & \multirow{3}{*}{$\begin{array}{l}1.98457 \mathrm{E}- \\
10^{* *}\end{array}$} \\
\hline Three meal & 16 & 49 & 4 & 0 & \\
\hline More than three & 4 & 7 & 11 & 7 & \\
\hline
\end{tabular}


Table.5 Chi-square for prevalence of obesity and food consumption frequency

\begin{tabular}{|c|c|c|c|c|c|}
\hline \multirow[t]{2}{*}{ Characteristics } & \multicolumn{3}{|c|}{ BMI category } & & \multirow[t]{3}{*}{$P$ value } \\
\hline & Underweight & Normal & Overweight & Obese & \\
\hline \multicolumn{5}{|l|}{ Ice cream } & \\
\hline Daily & 0 & 11 & 0 & 3 & \multirow{4}{*}{$\begin{array}{l}9.42656 \mathrm{E}- \\
07 * *\end{array}$} \\
\hline Weekly & 8 & 1 & 6 & 6 & \\
\hline Occasionally & 10 & 31 & 9 & 0 & \\
\hline Never & 2 & 13 & 0 & 0 & \\
\hline \multicolumn{6}{|l|}{ Chocolate } \\
\hline Daily & 0 & 0 & 0 & 3 & \multirow{4}{*}{$\begin{array}{l}1.01625 \mathrm{E}- \\
12 * *\end{array}$} \\
\hline Weekly & 1 & 13 & 6 & 5 & \\
\hline Occasionally & 11 & 43 & 9 & 1 & \\
\hline Never & 8 & 0 & 0 & 0 & \\
\hline \multicolumn{6}{|c|}{ Bakery product } \\
\hline Daily & 0 & 5 & 0 & 5 & \multirow{4}{*}{$\begin{array}{l}5.99085 \mathrm{E}- \\
07 * *\end{array}$} \\
\hline Weekly & 5 & 18 & 8 & 4 & \\
\hline Occasionally & 11 & 33 & 7 & 0 & \\
\hline Never & 4 & 0 & 0 & 0 & \\
\hline \multicolumn{6}{|l|}{ Street food } \\
\hline Daily & 0 & 1 & 3 & 1 & \multirow[t]{4}{*}{$0.173751311^{\mathrm{NS}}$} \\
\hline Weekly & 6 & 14 & 4 & 3 & \\
\hline Occasionally & 12 & 39 & 7 & 5 & \\
\hline Never & 2 & 2 & 1 & 0 & \\
\hline \multicolumn{6}{|l|}{ Dry fruits } \\
\hline Daily & 2 & 6 & 2 & 0 & \multirow[t]{4}{*}{$0.254483^{\mathrm{NS}}$} \\
\hline Weekly & 4 & 16 & 2 & 4 & \\
\hline Occasionally & 12 & 34 & 9 & 5 & \\
\hline Never & 2 & 0 & 2 & 0 & \\
\hline \multicolumn{6}{|l|}{ Cold drink } \\
\hline Daily & 0 & 0 & 0 & 0 & \multirow[t]{4}{*}{$0.083915^{\mathrm{NS}}$} \\
\hline Weekly & 6 & 13 & 8 & 8 & \\
\hline Occasionally & 10 & 43 & 7 & 1 & \\
\hline Never & 4 & 0 & 0 & 0 & \\
\hline
\end{tabular}


Table.6 Chi-square for prevalence of obesity and frequency of leisure time spent on different ways

\begin{tabular}{|c|c|c|c|c|c|}
\hline \multirow[t]{2}{*}{ Characteristics } & \multicolumn{4}{|c|}{ BMI category } & \multirow[t]{2}{*}{$P$ value } \\
\hline & Underweight & Normal & Overweight & Obese & \\
\hline \multicolumn{6}{|l|}{ Outdoor games } \\
\hline Daily & 6 & 41 & 2 & 2 & \multirow{4}{*}{$\begin{array}{l}2.00342 \mathrm{E}- \\
08^{* *}\end{array}$} \\
\hline Weekly & 4 & 13 & 0 & 0 & \\
\hline Occasionally & 8 & 2 & 10 & 6 & \\
\hline Never & 2 & 0 & 3 & 1 & \\
\hline \multicolumn{6}{|l|}{ Watching T. V } \\
\hline Daily & 4 & 44 & 10 & 9 & \multirow{4}{*}{$\begin{array}{l}4.92559 \mathrm{E}- \\
09^{* *}\end{array}$} \\
\hline Weekly & 0 & 9 & 3 & 0 & \\
\hline Occasionally & 2 & 0 & 0 & 0 & \\
\hline Never & 14 & 3 & 2 & 0 & \\
\hline \multicolumn{6}{|l|}{ Indoor game } \\
\hline Daily & 7 & 0 & 1 & 2 & \multirow{4}{*}{$\begin{array}{l}5.11587 \mathrm{E}- \\
13^{* *}\end{array}$} \\
\hline Weekly & 10 & 0 & 1 & 1 & \\
\hline Occasionally & 0 & 13 & 9 & 3 & \\
\hline Never & 3 & 43 & 4 & 3 & \\
\hline
\end{tabular}

Table.7 Chi-square for prevalence of obesity and frequency of participation in different activities in school

\begin{tabular}{|c|c|c|c|c|c|}
\hline \multirow[t]{2}{*}{ Characteristics } & \multicolumn{3}{|c|}{ BMI category } & & \multirow[t]{2}{*}{$P$ value } \\
\hline & Underweight & Normal & Overweight & Obese & \\
\hline \multicolumn{6}{|l|}{ Sports } \\
\hline Daily & 8 & 30 & 2 & 0 & \multirow{4}{*}{$\begin{array}{l}1.80636 \mathrm{E}- \\
12^{* *}\end{array}$} \\
\hline Weekly & 11 & 5 & 0 & 0 & \\
\hline Occasionally & 1 & 16 & 4 & 1 & \\
\hline Never & 0 & 5 & 9 & 8 & \\
\hline \multicolumn{6}{|l|}{ Drama } \\
\hline Daily & 20 & 3 & 0 & 0 & \multirow{4}{*}{$\begin{array}{l}1.35507 \mathrm{E}- \\
16^{* *}\end{array}$} \\
\hline Weekly & 0 & 3 & 2 & 0 & \\
\hline Occasionally & 0 & 15 & 2 & 6 & \\
\hline Never & 0 & 35 & 11 & 3 & \\
\hline \multicolumn{6}{|l|}{ Dance } \\
\hline Daily & 17 & 7 & 0 & 0 & \multirow{4}{*}{$\begin{array}{l}3.3722 \mathrm{E}- \\
11^{* *}\end{array}$} \\
\hline Weekly & 3 & 2 & 0 & 0 & \\
\hline Occasionally & 0 & 15 & 7 & 1 & \\
\hline Never & 0 & 32 & 8 & 8 & \\
\hline
\end{tabular}


Gautam and Jeong (2019) also reported that education of both the father and mother, occupation of both the father and mother were significantly associated with elevated BMI ( $p$ $<0.05)$.

\section{Food habit}

The result was found to be highly significant at $\mathrm{p}<0.01$, indicating that prevalence of obesity is dependent food habits of school going girls (Table 4). Shah et al., (2013) in their study also emphasized that frequency of intake of fast food had an impact on the prevalence of overweight; however the observations were not statistically significant when they conducted study on prevalence of overweight / obesity among school children in Mehsana district, India.

\section{Food consumption frequency of different items}

The results were found to be highly significant for of ice cream, chocolate and bakery products indicating that prevalence of obesity is dependent food consumption frequency (Table 5). Agrawal et al., (2017) also reported in their study conducted in Jaipur city that eleven obese adolescents had 75 to $100 \%$ excess calorie consumption, 5 adolescents had 50 to $74 \%, 4$ had 25 to $49 \%$ of excess calorie consumption (significant).

\section{Frequency of leisure time spent}

The result was found to be highly significant indicating that prevalence of obesity is dependent on frequency of leisure time spent on different ways (Table 6). This study was in line with Laxmaiah et al., (2007) who reported that obesity significantly less in children who participated in outdoor games than among non-participants and significantly higher in children watching television for long time.

\section{Participation in different activities in} school

The result was found to be highly significant indicating that prevalence of obesity is dependent on and frequency of participation in different activities in school (Table 7).

On the whole it was concluded that overweight and obesity among school going aged 10-18 years in Kumaun region of Uttarakhand was relatively high due to low level of parent education, taking non vegetarian diet and eating outside food, having more than three meals per day, eating sweet and fried food, eating ice cream, chocolate and bakery product more frequently, less participation in outdoor games, and as compared to indoor games, sitting and watching TV for long hours in free time. All these factors showed a strong association with a higher BMI lead to overweight and obesity in school going girls

\section{References}

Alok, P. Malay, P. and Divyeshkumar, V. 2012. A study on Prevalence of Overweight and Obesity in Adolescents of Urban \& Rural Area of Surat, Gujarat, National Journal of Medical Research, 2(3): 325-326.

Bharati, D.R. Deshmukh, P.R. and Garg, B.S. 2008. Correlates of overweight \& obesity among school going children of Wardha city, Central India, Indian $\mathbf{J}$ Med Res; 127(6): 539-43.

Campbell, K.J. Crawford, D.A. Salmon, J. Carver, A. Garnett, S.P. and Baur, LA. 2007. Associations between the home food environment and obesitypromoting eating behaviors in adolescence, Obesity, vol. 15, no. 3, pp. 719-730.

Agrawall, J.P. Gupta, V.K. Jain, M. and Agrawal, S. 2017. A study of 
prevalence of obesity among adolescents (10-19 years) in Jaipur city with special reference to lifestyle. International Journal of Contemporary Pediatric; 4(4):1461-1465.

Laxmaiah A, Nagalla B, Vijayaraghavan K, and Nair M. 2007. Factors affecting prevalence of overweight among 12- to 17-year-old urban adolescents in Hyderabad, India. Obesity (Silver Spring);15:1384-90.

Shah, J. S., Patel, P. K. and Patel, B. 2013. Determinants of overweight and obesity among school children in Mehsana District, India. Ann Trop Med Public Health [serial online] 2013 [cited 2019
Sep 24]; 6:408-12. Available from: http://www.atmph.org/text.asp?2013/6/ 4/408/127775.

Gautam, S. and Jeong, H. S. (2019) Childhood Obesity and its Associated Factors among School Children in Udupi, Karnataka, India. J Lifestyle Med. 9(1): 27-35.

WHO. 2007. World Health Organization. Growth reference 5-19 years. [cited 2019 June]. Available from: http://www.who.int/growthref/who2007 _bmi_for_age/en/ [Google Scholar]

\section{How to cite this article:}

Janki Joshi and Ekroop Kaur. 2019. Factors Associated with Obesity among School Going Girls of Kumaun Region of Uttarakhand, India. Int.J.Curr.Microbiol.App.Sci. 8(10): 960-967. doi: https://doi.org/10.20546/ijcmas.2019.810.112 